\title{
BASILAR INVAGINATION SECONDARY TO HYPOPLASIA OF THE CLIVUS - IS THERE INDICATION FOR CRANIOCERVICAL FIXATION?
}

\author{
INVAGINAÇÃO BASILAR SECUNDÁRIA À HIPOPLASIA DO CLIVO - HÁ INDICAÇÃO PARA \\ FIXAÇÃO ÇRÂNIO-CERVICAL? \\ INVAGINACIÓN BASILAR SECUNDARIA A LA HIPOPLASIA DEL CLIVUS - ¿HAY INDICACIÓN \\ PARA LA FIJACIÓN CRÁNEO-CERVICAL?
}

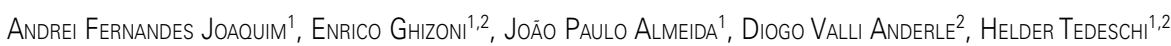

\begin{abstract}
The posterior fossa decompression is a form of treatment suggested for patients with basilar invagination (BI) secondary to hypoplasia symptomatic of the clivus and atlantoaxial alignment preserved. Based on the fact that the worsening of cranial-cervical kyphosis (decrease of clivus-canal angle to less than $150^{\circ}$ ) can result in anterior brainstem compression, we propose that some patients may benefit from the cranio-cervical fixation. We present a case report of a patient with $\mathrm{BI}$ secondary to clivus hypoplasia who underwent cranio-cervical fixation in extension, with a reduction in clivus-canal angle and improvement of symptoms without posterior fossa decompression.
\end{abstract}

Keywords: Platybasia; Decompressive craniectomy; Cranial fossa, posterior; Treatment outcome.

\section{RESUMO}

A descompressão da fossa posterior é uma das formas de tratamento sugeridas para pacientes com invaginação basilar (IB) secundária a hipoplasia sintomática de clivo e alinhamento atlanto-axial preservado. Baseado no fato de que a piora da cifose crânio-cervical (diminuição do ângulo clivo-canal para menos do que $150^{\circ}$ ) pode resultar em compressão anterior do tronco cerebral, propomos que alguns pacientes podem se beneficiar da fixação crânio-cervical. Apresentamos um caso de paciente com IB secundária a hipoplasia de clivo submetido à fixação crânio-cenical em extensão, com diminuição do seu ângulo clivo-canal e melhora dos sintomas, sem descompressão da fossa posterior.

Descritores: Platibasia; Craniectomia descompressiva; Fossa craniana posterior; Resultado de tratamento.

\section{RESUMEN}

La descompresión de la fosa posterior es una forma de tratamiento sugerido para los pacientes con invaginación basilar (IB) secundaria a hipoplasia sintomática del clivus con alineación atlantoaxial preservada. Con base en el hecho de que el empeoramiento de la cifosis cráneo-cervical (reducción del ángulo clivus-canal para menos de 150') puede resultar en la compresión del tronco cerebral anterior, se propone que algunos pacientes pueden beneficiarse de la fijación craneocervical. Presentamos un paciente con IB secundaria a la hipoplasia del clivus sometido a fijación cráneo-cenvical en extensión, con reducción del ángulo clivus-canal y mejora de los síntomas sin descompresión de la fosa posterior.

Descriptores: Platisbasia; Craniectomía descompresiva; Fosa craneal posterior; Resultado del tratamiento.

\section{INTRODUCTION}

Basilar invagination $(\mathrm{BI})$ is a developmental anomaly of the occipital bone and upper cervical spine defined when the tip of the odontoid process was at least $2.5 \mathrm{~mm}$ above Chamberlain's line, resulting in an abnormally high vertebral column prolapsed into the skull base. ${ }^{1}$ Of note, $\mathrm{BI}$ is a radiographic finding and not a diagnosis, once it's associated with many developmental anomalies. ${ }^{2}$ Protrusion of the odontoid is often associated with a horizontal clivus and craniocervical kyphosis. ${ }^{3}$ These conditions can result in ventral compression at the spinomedullary junction, with severe neurological impairment. ${ }^{4}$

In one of the largest series reported about $\mathrm{BI}$, treatment was based on the division of these patients in two groups, based on the presence or absence of instability:

Group A) Patients with atlantoaxial dislocation, with the tip of the odontoid process protruded into the foramen magnum and above the Chamberlain line, McRae line of foramen magnum and Wackenheim's clival line. This group main characteristic is the presence of a clear element of instability of the region that is manifested by the tip of the odontoid process distancing itself from the anterior arch of the atlas or the lower end of the clivus. The patients might have Chiari malformation with tonsilar herniation, and the treatment is based on the reduction of $\mathrm{C} 1-2$ instability, once a real "lysthesis" can be found in some cases, with occipital traction or $\mathrm{C} 1-2$ distraction and fixation. Transoral decompression can be used in patients without reduction of the instability, if a fixed anterior compression is presented. ${ }^{5}$

Group B) Patients with the tip of the odontoid process above the Chamberlain's line, but presenting a normal alignment of the clivus and odontoid process. The tip of the odontoid is below the Wackenheim's clival line and the McRae's line. The alignment of the anterior arch of the atlas, the odontoid process and the inferior aspect of the clivus remains normal, with no instability, probably secondary to a complete clivus hypoplasia (basiocciput clivus). The atlanto-axial is also normal. The distance between the ponto-medullary junction and the odontoid process is markedly reduced. Posterior cranial fossa volume can be markedly reduced in this group and Chiari malformation can be commonly found. The treatment usually proposed in these cases is foramen magnum decompression without craniocervical fixation. ${ }^{5}$

We presented an illustrative case to justify the hypothesis that some patients in Group B can be treated with craniocervical fusion to decrease craniocervical kyphosis and to avoid anterior brainstem stress due to instability. Consent was obtained from the patient presented in this paper.

1. Universidade Estadual de Campinas (Unicamp), Campinas, SP. Brazil.

2. Centro de Neurocirurgia e Cirurgia de Coluna de Campinas, Campinas, SP. Brazil.

Study conducted at Neurosurgery Division, Universidade Estadual de Campinas (Unicamp), Campinas-SP, Brazil.

Correspondence: Disciplina de Neurocirurgia, Universidade Estadual de Campinas, SP, Brasil. Rua Antonio Lapa, 280, Ap 506. 13025-240, Campinas-SP, Brazil. andjoaquim @yahoo.com 


\section{Case Report}

We present the case of a 60-year-old man who initially present to our clinic with complaints of cervical pain for the last 2. He stated that his condition had worsened in the past year with occurrence of progressive weakness in both arms and legs, with presence of paresthesias and numbness in both hands. Physical examination revealed bilateral hand and left arm paresis associated with loss of dexterity, which did not allow the patient to write. He was able to walk without assistance, with an objective motor deficit in the lower extremities. All the tendon reflexes were exacerbated. He did not present any sign of cranial nerve deficit. Of note, his symptoms intensity decrease when he holds his head in extension, worsening the pain and numbness when in flexion - a clear mechanical instability.

CT scanning and MR imaging showed the presence of a BI, with the tip of the odontoid process above the Chamberlain's line but below the Wackenheim's clival line and the McRae's line. A clivuscanal angulation in flexion of $93^{\circ}$ was measured.

This patient underwent an occipital-C2-3 fusion in extension, without posterior fossa decompression. Due to his extremely thin posterior occipital bone, we are not able to put screws, using a combination of plates and wires, as shown in Figure 1. We used C2 pars screws and C3 lateral mass screws.

Postoperatively, he reported important improvement for walking and the weakness in his superior extremities was considerably reduced. After one year of follow-up, the patient still improving, presenting only occasional paresthesias in both arms. He was able to return to work as a writer without limitations. The follow up CT scan showed an increase in the clivus-canal angle, from $93^{\circ}$ to $127^{\circ}$.

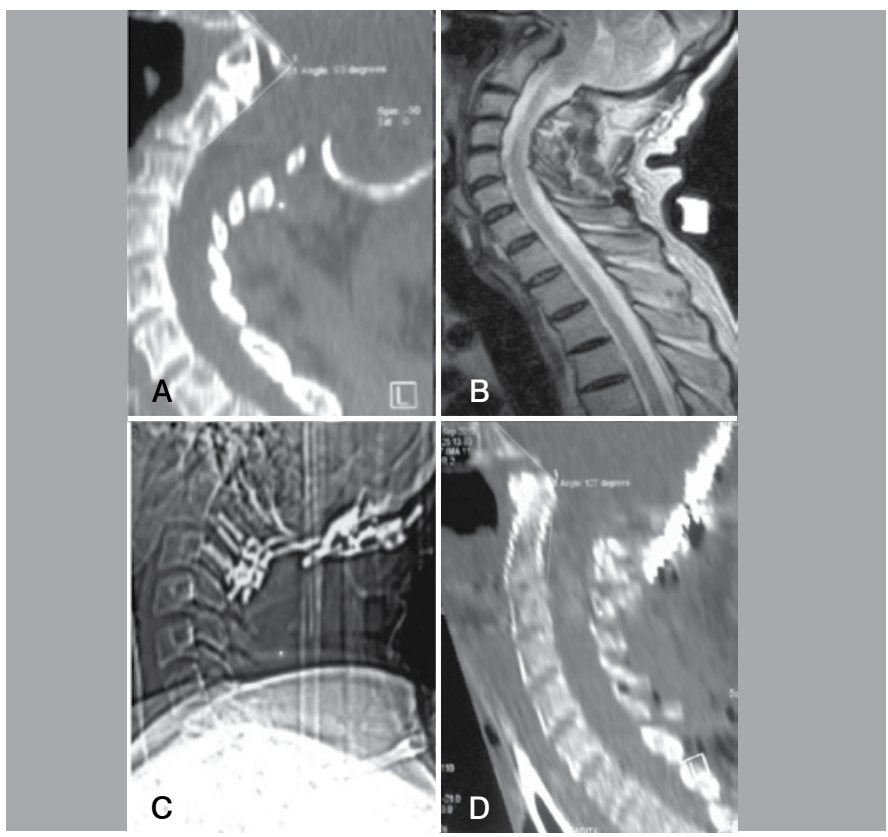

Figure 1. (A) Preoperative CT scan (sagittal reconstruction) showing the patient clivus-canal angle of 930; (B) A sagittal T2-weighted cervical MRI with a basilar invagination secondary to clivus hypoplasia and ventral brainstem compression; (C) Post-operative plain radiograph showing an occipito-C2-3 fixation; (D) A CT scan (sagittal reconstruction) showing the final clivus-canal angle of 1270 decreasing the stress in the brainstem.

\section{DISCUSSION}

Many patients with $\mathrm{BI}$ can fail to show improvement after posterior fossa decompression. ${ }^{4,6}$ Posterior fossa decompression can also exacerbate cervicomedullary compression over the odontoid. ${ }^{3}$ Treatment of neurological symptoms of the patients with $\mathrm{BI}$ but with a normal alignment of the clivus and C1-2, probably secondary to clivus hypoplasia, is based on posterior foramen magnum decompression. ${ }^{5}$ However, even with a normal alignment, abnormal deformative stresses in the brainstem and spinal cord can lead to neurological worsening in the presence of cervicomedullary kyphosis, specially in patients with a kyphotic clivus-canal angle $\left(<130^{\circ}\right){ }^{3,7}$ In an elegant study of five cases, Henderson et al., ${ }^{3}$ performed a finite element analysis (FEA), a computational means of predicting stress due to load, deformity and strain, of neuraxial preoperative and postoperative (suboccipital decompression, reduction of the abnormal clivus-canal angle to correct brainstem deformity and fusion). They concluded that normalization of the clivus-canal angle was associated with the reduction of deformative stress in FEA, resulting in clinical improvement, as observed in our case.

In normal individuals, the clivus-canal angle should range from $150^{\circ}$ to $180^{\circ}{ }^{2}$ Some authors advocate that its evaluation for infer ventral brainstem compression (VBSC) has some pitfalls, as it follows: 1) it's an indirect mean for evaluation of brainstem compression; 2) only osseous structures were taken in account in the anterior foramen magnum region (it does not include soft retro-odontoid tissue), and 3) it has also a dynamic behavior, increasing in extension and decreasing in flexion, which can lead to misreading of the measured value (range of about $\left.30^{\circ}\right)^{2}$ As an alternative method for evaluate VBSC, Grabb et al., ${ }^{6}$ based on the analysis of their surgical results of 40 patients treated with diagnosis of Chiari I malformation, proposed a measurement to quantify VBSC, also known as the pB-C2. This was obtained based on a line draw between the basion and the postero-inferior aspect of $\mathrm{C} 2$ body. A line perpendicular to this line was drawn through the odontoid tip to the ventral dura and the distance representing the amount of ventral canal encroachment was measured. All the patients with a pB-C2 of less than $9 \mathrm{~mm}$ were treated successfully with posterior fossa decompression alone. Patients with $9 \mathrm{~mm}$ or more required reduction of the VBSC before posterior fossa decompression. Grab-Oakes measurement, therefore, might be considered an objective tool to quantify VBSC. It is especially adequate, in our view, for further evaluation of patients who will undergo posterior fossa decompression and may require an additional procedure (ventral decompression and/ or concomitant craniocervical fusion).

We believe that some patients with $\mathrm{BI}$ secondary to clivus hypoplasia may have VBSC and craniocervical instability. This can be clearly exemplified by the case of our patient, who was not submitted to posterior fossa decompression, but achieved dramatically improvement of his symptoms after reduction and stabilization of his craniocervical kyphosis, what decreased the stress of his neural tissue.

Due to a wide range of clinical and radiological presentation of $\mathrm{Bl}$, we believe that further studies are required for a better definition of the patients who may clear be benefited of an occipito-cervical fusion. Future studies should evaluate the relationship of the clivus-canal angle and Grabbs-Oakes measurement in patient's outcome.

All authors declare no potential conflict of interest concerning this article.

\section{REFERENCES}

1. Chamberlain WE. Basilar impression (Platybasia): a bizarre Developmental anomaly of the occipital bone and upper cervical spine with striking and misleading neurologic nanifestations. Yale J Biol Med. 1939;11(5):487-96.

2. Smoker WR. Craniovertebral junction: normal anatomy, craniometry, and congenital anomalies. Radiographics. 1994:14(2):255-77.

3. Henderson FC, WilsonWA, Mott S, Mark A, Schmidt K, Berry JK, et al. Deformative stress associated with an abnormal clivo-axial angle: a finite element analysis. Surg Neurol Int. 2010;16(1):11-30.

4. Botelho RV, Neto EB, Patriota GC, Daniel JW, Dumont PA, Rotta JM. Basilar invagination: craniocervical instability treated with cervical traction and occipitocervical fixation. Case report. J Neurosurg Spine. 2007;7(4):444-9.

5. Goel A. Basilar invagination, Chiari malformation, syringomyelia: a review. Neurol India. 2009;57(3):235-46

6. Grabb PA, Mapstone TB, Oakes WJ. Ventral brain stem compression in pediatric and young adult patients with Chiari I malformations. Neurosurgery. 1999:44(3):520-7.

7. Nagashima C, Kubota S. Craniocervical abnormalities. Modern diagnosis and a comprehensive surgical approach. Neurosurg Rev. 1983;6(4):187-97. 